\title{
OPERATING PARAMETERS AND ENVIRONMENTAL INDICATORS OF DIESEL ENGINES FED WITH CROP-BASED FUELS
}

\author{
Grzegorz Dzieniszewski ${ }^{\mathrm{a}, c^{*}}$, Maciej Kuboń ${ }^{\mathrm{b}, \mathrm{c}}$, Miroslav Pristavka $^{\mathrm{d}}$, Pavol Findura ${ }^{\mathrm{e}}$
}

${ }^{a}$ Faculty of Mechanics and Technology of Rzeszow University of Technology in Stalowa Wola, e-mail: g.dzieniszew@prz.edu.pl. ORCID 0000-0002-2712-1131

b Department of Production Engineering, Logistics and Applied Computer Science, Faculty of Production and Power Engineering, University of Agriculture in Kraków, ORCID 0000-0003-4847-8743

c Eastern European State College of Higher Education in Przemyśl

${ }^{\mathrm{d}}$ Department of Quality and Engineering Technologies, Slovak University of Agriculture in Nitra, Slovak Republic e-mail: miroslav.pristavka@uniag.sk, ORCID 0000-0002-7957-4765

${ }^{\mathrm{e}}$ Department of Machines and Production Biosystems, Slovak University of Agriculture in Nitra, email: pavol.findura@uniag.sk, ORCID 0000-0001-6050-4647

*Corresponding author: e-mail: g.dzieniszew@prz.edu.pl

\begin{tabular}{|c|c|}
\hline ARTICLE INFO & ABSTRACT \\
\hline $\begin{array}{l}\text { Article history: } \\
\text { Received: February } 20211 \\
\text { Received in the revised form: } \\
\text { March } 2021 \\
\text { Accepted: April } 2021\end{array}$ & $\begin{array}{l}\text { A comparative analysis of performance of Diesel engines fuelled by } \\
\text { diesel oil, methyl ester of rapeseed oil and raw rapeseed oil was per- } \\
\text { formed. The analysis of external characteristics of engines powered by } \\
\text { various fuel types was accepted for an assessment. Engine performance } \\
\text { rates were analysed while attention was paid to power courses, moment, }\end{array}$ \\
\hline $\begin{array}{l}\text { Key words: } \\
\text { combustion engine, } \\
\text { crop-based fuels, } \\
\text { external characteristics of combustion } \\
\text { engines }\end{array}$ & $\begin{array}{l}\text { unit fuel consumption and hour fuel consumption, exhaust fumes tem- } \\
\text { perature and exhaust smoke. Operation effectiveness of engines was as- } \\
\text { sessed when they were fed with various fuel types and optimal propor- } \\
\text { tions of fuel mixtures were indicated. Environmental aspects of } \\
\text { powering the engines with traditional fuels and crop-based fuels were } \\
\text { analysed. The total } \mathrm{CO}_{2} \text { emission in the entire process of manufacturing } \\
\text { and combustion of fuels was accepted as a criterion. A simplified eco- } \\
\text { nomic analysis was performed in the aspect of the underlying purpose } \\
\text { of using crop-based fuels for propulsion of piston engines. Conclusions } \\
\text { and recommendations that indicate directions of development concern- } \\
\text { ing the analysed issue were prepared. }\end{array}$ \\
\hline
\end{tabular}

\section{Introduction}

Engine feed with crop-based fuels is a complex issue that cannot be easily interpreted objectively. Therefore, it is advisable to apply a complex approach to the problem with the use of a measurement of performance rates (Baczewski and Kałdoński, 2005). Technical, environmental, and economic parameters were such rates. Such a multi-layer analysis enables to objectively assess the investigated issue. 
Besides technical aspects and constructional solutions, including specificity of the national economy of a country in the aspect of operation costs, excess in crop production and power autonomy measured with diversification of power resources, is of key meaning for assessment of advisability of biofuels application.

An alternative use of biofuels for feeding piston engines should be analysed according to basic criteria: economic, environmental and a technical one. Moreover, a social and economic aspect cannot be omitted.

Such solutions derive from the fact that crude oil is a currently basic resource for production of fuels. In the period of the recent fifty years, consumption of crude oil has increased by several hundred percent (Holt, 2004). Specificity of technical solutions used for propulsion delivery vans, trucks and farm vehicles causes that a Diesel engine is the prevailing propulsion source which determines a progressive growth of diesel oil consumption (Szlachta, 2002).

A geopolitical and economic situation of Poland influences the fact that crude oil for production of fuel is imported. It results in various negative effects such as a considerable variability of fuel prices and an unpredictable price trend of fuels. Such situation has economic and social effects in the form of periodic economic problems of various fields of economy with the most burning issues in the transport branch and mainly difficulties in agriculture (Motowidlak, 2016).

Presently, the market of biofuels is mainly based on the I generation technologies or on production of biofuels from edible agricultural raw materials (Żołądkiewicz, 2018). The European market marks an excess of agricultural and food production which determines a necessity to reorganize production types into different ones, that are more economically justified (Bechtold, 2002). In Poland, an interest in agricultural production directed at bio-power energy sources comes in waves, which is a fact (Tys et al., 2003).

\section{Analysis of the state of the issue}

Trends of interest in biofuels are determined with no stability of the crude oil market, social issues of formation of new workplaces in agriculture which is also related to restructuring of agriculture and mainly to aspirations of agricultural production optimization with regard to stability and certainty of achieved economical results.

An increase of the interest in fuel production from organic sources could have been observed for several years. It results from several overlapping factors: a high price of crude oil, aspiration of some countries to energy sovereignty, counteracting the global warming and a limited number of non-renewable resources (Jonek-Kowalska, 2016).

Economic aspects are also important. They should be analysed from two points of view., On one hand, taking into consideration a possibility of returning contaminated areas to crop production and on the other hand, considering actions that aim at reduction of $\mathrm{CO}_{2}$ emission (Bocheński, 2006).

Rapeseed is a basic crop that is used in Poland for production of biofuels. Currently, $85 \%$ of rapeseed is designated for food. The remaining part is processed into biofuels with predominance of rapeseed esters (Tys et al., 2003). Trzebinia Refinery has a dominant position in this respect. Moreover, similar production is carried out by many smaller esterification establishments with an indication of the region of Lublin which intensively develops biofuels production (Jankowiak, 2001). 
Operating parameters...

The analysis of production costs of rapeseed fuel is quite complex. Since, the final economic indices are influenced by numerous factors with prevailing rapeseed cultivation costs, influenced, inter alia, by agrotechnical treatments, a sowing material type, intensity of fertilization and indispensable crop protection treatments (Pawlak, 2000). The second group includes costs of oil pressing that strongly depend on the possibility of using pomace. It should be reminded that from one tonne of rapeseed, ca. $400 \mathrm{~kg}$ of rapeseed oil and $600 \mathrm{~kg}$ of rape cake is obtained. It is possible and advisable to use pomace as feed or as a calorific energy carrier.

The assumed criteria that determine the quality of the rapeseed fuel are the third factor that influences the costs. The esterification process is the most popular one, which additionally considerably increases a biofuel price since it requires a chemical apparatus and the use of additional chemical raw materials. It is also possible to use unprocessed rapeseed oil for propulsion of Diesel engines which enables to avoid costs incurred with relation to the esterification process but on the other hand it requires interference with the fuel system of the engine (Dzieniszewski and Piekarski, 2006).

However, the situation is complicated by the fact that during esterification, considerable amounts of the glycerol phase which is a needed semi-finished product of various industry branches are obtained. Derivation of glycerine enables reduction of the final costs of esterification (Bocheński, 2003).

Therefore, an economic analysis of application of various biofuels must be performed thoroughly with consideration of some non-material but socially very important factors which, inter alia, include an increase in the number of workplaces in agriculture and recovery of chemically destroyed areas for agricultural production areas.

\section{The objective of the paper}

The issue of clear and measurable determination of organic, economic and operation parameters such as power, moment, unit, and hourly fuel consumption for the engine powered with alternative fuels is complex difficult for clear interpretation. A prevailing problem is no explicit and objective criterion of assessment. Therefore, the objective of the paper is an attempt to compare parameters of the engine fuelled with diesel oil, rapeseed oil and rapeseed oil ester together with the assessment of environmental effectiveness measured with carbon dioxide emission and with economic prerequisites measured with a price of mentioned fuels and their properties that influence the size of consumption.

\section{Methodology of work}

Environmental factors related to biofuel production may be objectively measured with $\mathrm{CO}_{2}$ emission. Energy inputs are incurred during the entire process that leads to fuel generation. Assuming that from one hectare, 3.5 tonnes of rape seeds is obtained, it may be assumed that it will enable to press ca. 1.35 tonnes of rapeseed oil from which 1.32 tonnes of rapeseed oil esters may be obtained in the esterification process (Dzieniszewski, 2008). The rapeseed cultivation, mechanized agrotechnical treatments and logistic tasks will cause emission of $\mathrm{CO}_{2}$ in the amount of ca. 1.3 tonnes per hectare, the process of pressing oil will cause emission of ca. 0.7 tonnes of $\mathrm{CO}_{2}$ per hectare, whereas in the esterification process for production 
of the energy indispensable in the process, ca. 0.25 tonnes of $\mathrm{CO}_{2}$ will be generated (Bocheński, 2006).

Methyl esters of rapeseed oil that are in accordance with Orlen specification and marked as Bioester B100 were used in the research works. Bioester B100 is formed in the transesterification process of plant oils with methanol and has similar physico-chemical properties to diesel oil, it is manufactured based on the rapeseed oil (RME). Diesel oil used in the studies, that is in accordance with a specification of Orlen for the brand name Ekodiesel Ultra meets the requirements set forth in the Resolution of the Minister of Economy as of 9 October 2015 on the quality requirements for liquid fuel (Journal of Laws as of 23 October 2015, item 1680), the Resolution of the Minister of Economy as of 9 October 2015 on the methods of testing of liquid fuel quality (Journal of Laws of 23 October 2015, item 1679) 2015 and the requirements of the Polish Standard PN-EN 590 - automotive road fuels - Diesel oil - Requirements and test methods. Rapeseed oil used in the research was a product of ZT in Bodaczów and its brand name is raw rapeseed oil.

Mixtures used in the studies with a varied percentage share of traditional fuel and biofuel were made of the above-mentioned base fuels.

Methodology of the paper is a compilation of traction tests performed for Volksvagen Golf 1600, laboratory tests performed for S-4003 engine, economic assessment, and reference to the existing scientific achievements in the research field. Technical parameters, total $\mathrm{CO}_{2}$ emission and fuel prices are prevailing indices.

\section{Results and analysis}

The obtained results prove that $\mathrm{CO}_{2}$ emission is higher when biofeul is used than in case of using fuels from crude oil (Lotko, 2007). Figure 1 presents a comparison of energy consumption measured with the final $\mathrm{CO}_{2}$ emission from a car for manufacturing of diesel oil from crude oil and biodiesel obtained from rapeseed oil.

The presented data show that the total emission that covers the entire process of manufacturing of compared fuels i.e., esters from rapeseed and diesel oil from crude oil and measured with the emission level from cars is much higher in case of crop-based fuels.

However, the obtained results do not allow the formulation of clear conclusions since during the cultivation of rapeseed, considerable amounts of $\mathrm{CO}_{2}$ are absorbed in the photosynthesis. Moreover, energy and environmental balance improves the possibility of using the pomace.

Referring general emission levels (Fig. 1) to a particular car with average fuel consumption that is 5 litres of diesel oil, one may compare emission levels for diesel oil, mixture of $80 \%$ of diesel oil and $20 \%$ of esters (B20) and for fuel which in $100 \%$ is a rape seed oil ester (B100). Such comparison is presented in Fig. 2.

It should be recalled that the calorific value of diesel oil is $42 \mathrm{MJ} \cdot \mathrm{kg}^{-1}$, whereas the calorific value of rapeseed oil ester is $37 \mathrm{MJ} \cdot \mathrm{kg}^{-1}$. It follows that consumption of rapeseed oil esters must be higher at least by $15 \%$ with reference to diesel oil consumption.

Clear determination of the impact of a fuel type on the content of toxic components in exhaust fumes is quite difficult since determined with many factors. According to the authors' own research that was performed for engines of Ursus C360 and Ursus 902 tractors, one may notice that application of rapeseed oil esters when powering with diesel oil causes reduction of hydrocarbons $\mathrm{HC}$, reduction of carbon oxide $\mathrm{CO}$ emission and reduction of exhaust smoke 
Operating parameters...

measured with emission of solid particles PM, whereas it raises the level of nitric oxide emission NOx (Fig. 3)

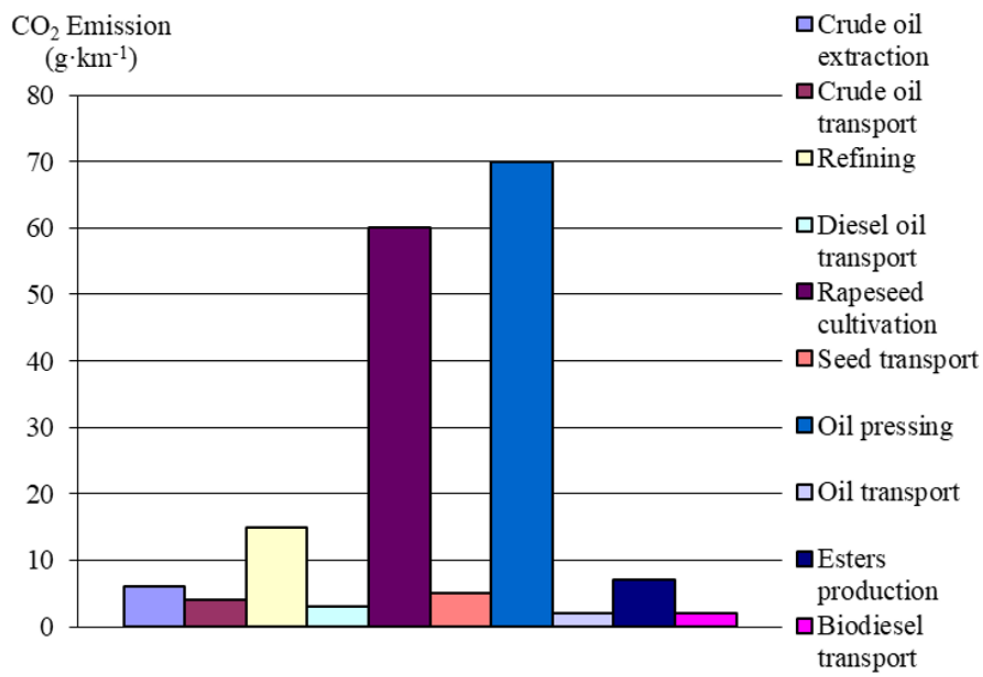

Figure 1. Comparison of $\mathrm{CO}_{2}$ emission for a car powered by diesel oil and esters of rapeseed oil

Source: Author's own study based on: Bocheński C.: Assessment of energy inputs and emission of gases at production of esters of rapeseed oil.

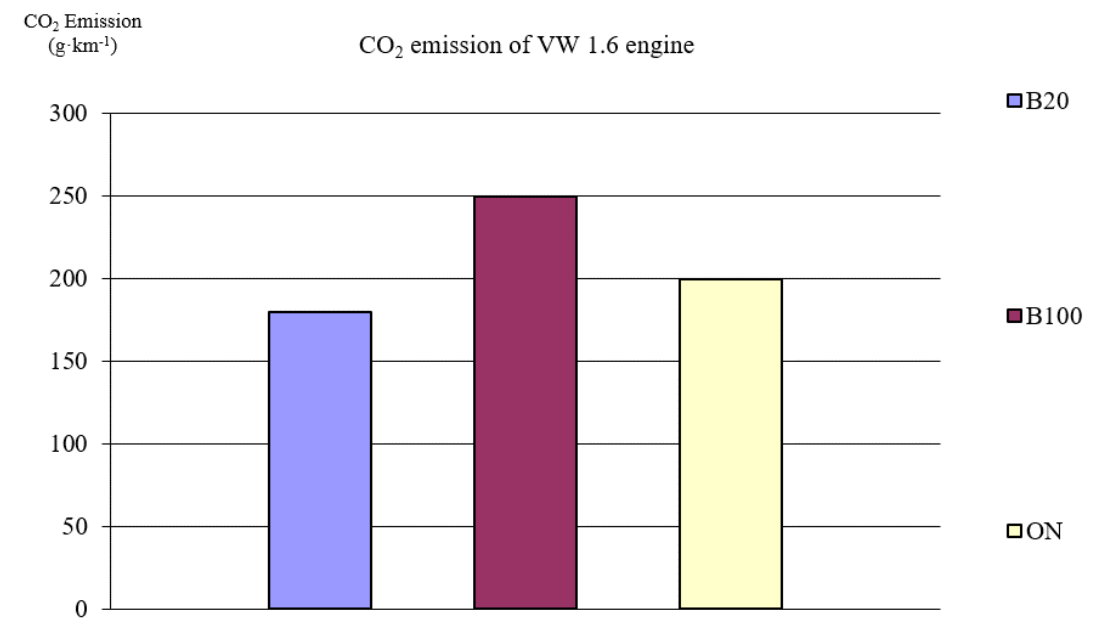

Figure 2. Comparison of $\mathrm{CO}_{2}$ emission with powering of various fuels 
Toxic components of exhaust gases when fuelled with DO and esters

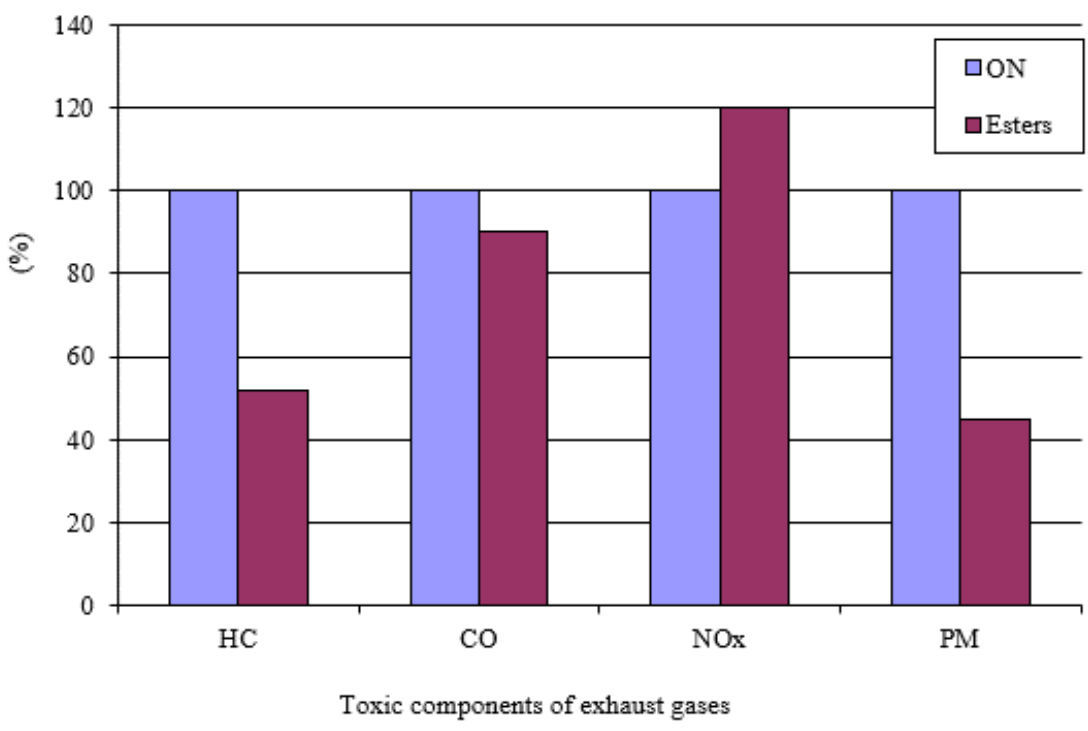

Figure 3. Level of emission of toxic components of fumes when powered with diesel oil and esters of rapeseed oil

$\mathrm{CO}_{2}$ emission is inseparably linked to energy consumption and cost efficiency of the fuel production process. However, a fuel price depends mainly on the price of raw material, namely rapeseed in case of biofuels and crude oil in case of diesel oil.

Although, the biofuel price should be determined with prices of rapeseed, the correlation with diesel oil prices is stronger. The price list of the analysed fuels is presented in Table 1.

Table 1.

Price list of analysed fuels

\begin{tabular}{lcccccc}
\multicolumn{2}{l}{ Paliwa hurt PKN Orlen S.A. } \\
\hline Data zm. & Pb98 & Pb95 & ON & ON & BIO & Ekoterm \\
& & & Ekodusel & Arktyczny2 & 100 & Plus \\
$2021-03-20$ & 4192 & 4036 & 4000 & 4265 & - & 2670 \\
\hline
\end{tabular}

In order to assess the operation parameters of a Diesel engine powered by various fuels, laboratory studies were performed consisting in performance of external characteristics of engine S-4003 powered by raw rapeseed oil equipped with the heating system that ensures the temperature of rapeseed oil of ca. $55^{\circ} \mathrm{C}$ at the exit to the pump (Fig. 4). 


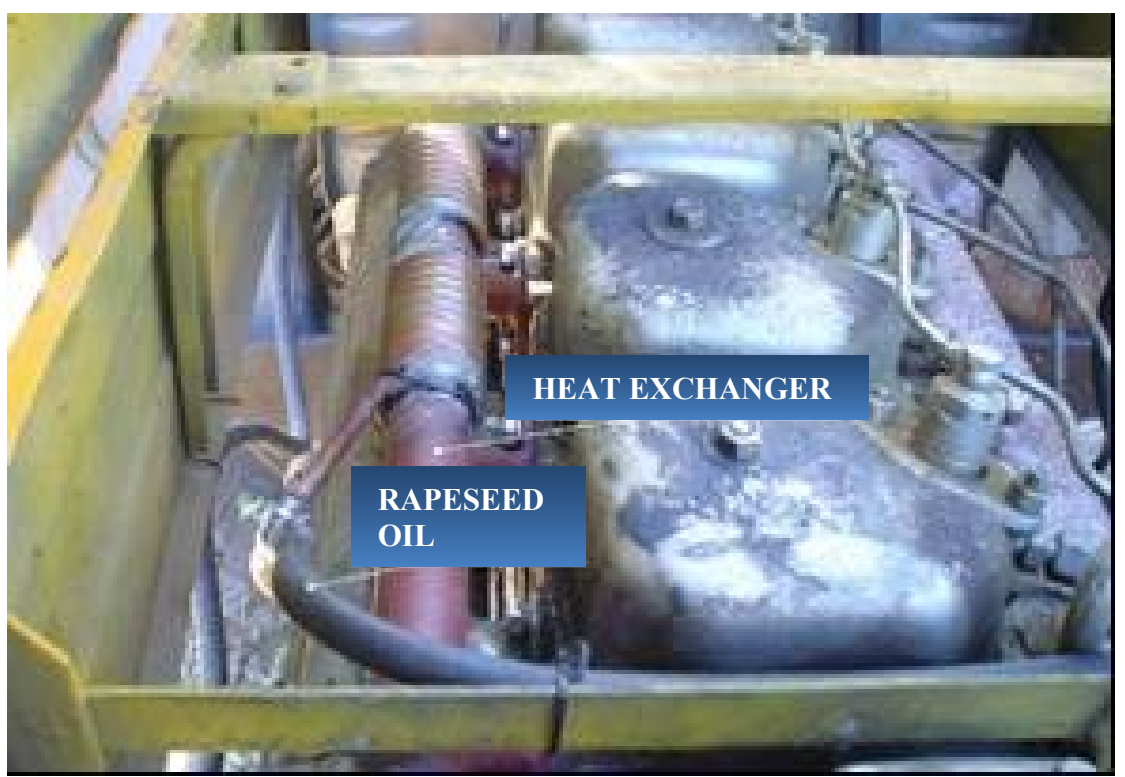

Figure 4. Heating system of raw rapeseed oil

Parameters measured at the laboratory stand and calculated for a particular type of an engine break, were presented in table $2 a-c$.

Table 2a.

Engine operation parameters $S$-4003 powered by various fuel types

\begin{tabular}{cccccccccc}
\hline $\begin{array}{c}\mathrm{n} \\
(\text { rot.min }\end{array}$ & $\begin{array}{c}\mathrm{P} \\
(\mathrm{kG})\end{array}$ & $\begin{array}{c}\mathrm{t} \\
(\mathrm{s})\end{array}$ & $\begin{array}{c}\mathrm{T} \\
\left({ }^{\circ} \mathrm{C}\right)\end{array}$ & $\begin{array}{c}\mathrm{Mo} \\
(\mathrm{Nm})\end{array}$ & $\begin{array}{c}\mathrm{Ne} \\
(\mathrm{kW})\end{array}$ & $\begin{array}{c}\mathrm{Gh} \\
\left(\mathrm{kg} \cdot \mathrm{h}^{-1}\right)\end{array}$ & $\begin{array}{c}\mathrm{ge} \\
\left(\mathrm{g} \cdot \mathrm{kWh}^{-1}\right)\end{array}$ & $\begin{array}{c}\mathrm{Ne} \\
\mathrm{R} \cdot \mathrm{Ne}^{-1} \mathrm{ON}\end{array}$ & $\begin{array}{c}\mathrm{ge} \\
\mathrm{OR} \cdot \mathrm{ge}^{-1} \mathrm{ON}\end{array}$ \\
\hline 2200 & 25 & 11 & 580 & 175.4 & 40.4 & 16.4 & 405.1 & 96.0 & 127.3 \\
2000 & 25 & 11 & 580 & 175.4 & 36.7 & 16.4 & 445.6 & 94.0 & 106.4 \\
1800 & 25.6 & 15 & 580 & 179.6 & 33.8 & 12.0 & 354.6 & 95.7 & 120.6 \\
1600 & 25.8 & 17 & 550 & 181.0 & 30.3 & 10.6 & 349.2 & 96.9 & 125.3 \\
1400 & 26.3 & 18 & 530 & 184.5 & 27.0 & 10.0 & 369.8 & 98.9 & 101.2 \\
1200 & 26 & 22 & 500 & 182.4 & 22.9 & 8.2 & 357.1 & 99.2 & 110.9 \\
1100 & 25.2 & 28 & 480 & 176.8 & 20.4 & 6.4 & 315.8 & 99.2 & 128.3 \\
\hline
\end{tabular}


Grzegorz Dzieniszewski, Maciej Kuboń, Miroslav Pristavka, Pavol Findura

Table 2b.

Engine operation parameters $S-4003$ powered by various fuel types

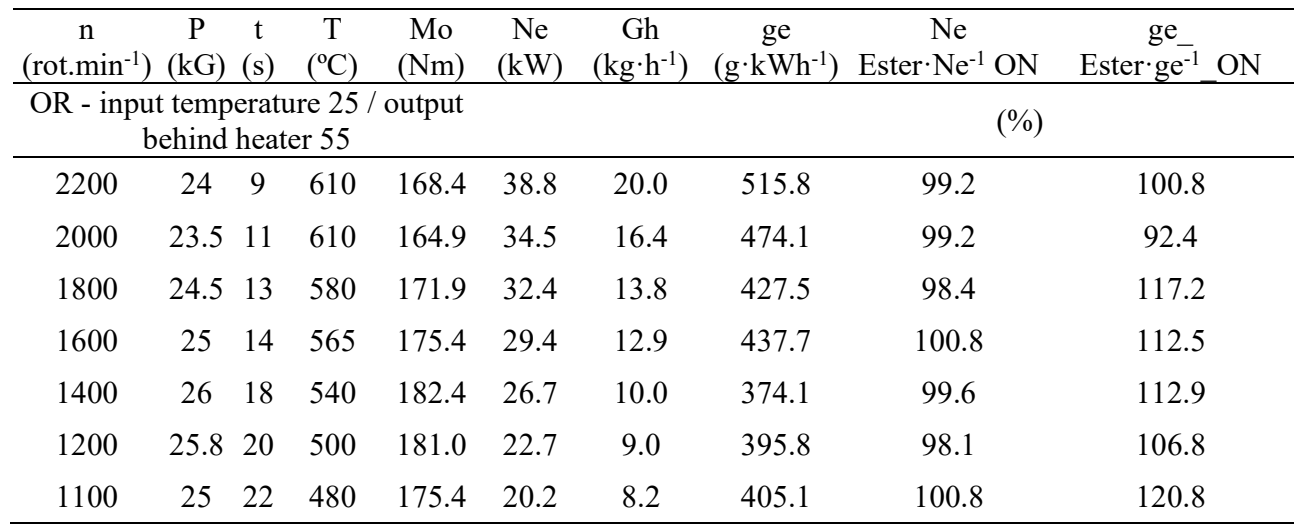

Table 2c.

Engine operation parameters S-4003 powered by various fuel types

\begin{tabular}{cccccccccc}
\hline $\begin{array}{c}\mathrm{n} \\
(\text { rot.min }\end{array}$ & $\begin{array}{c}\mathrm{P} \\
(\mathrm{kG})\end{array}$ & $\begin{array}{c}\mathrm{t} \\
(\mathrm{s})\end{array}$ & $\begin{array}{c}\mathrm{T} \\
\left({ }^{\circ} \mathrm{C}\right)\end{array}$ & $\begin{array}{c}\mathrm{Mo} \\
(\mathrm{Nm})\end{array}$ & $\begin{array}{c}\mathrm{Ne} \\
(\mathrm{kW})\end{array}$ & $\begin{array}{c}\mathrm{Gh} \\
\left(\mathrm{kg} \cdot \mathrm{h}^{-1}\right)\end{array}$ & $\begin{array}{c}\mathrm{ge} \\
\left(\mathrm{g} \cdot \mathrm{kWh}^{-1}\right)\end{array}$ & $\begin{array}{c}\mathrm{Ne} \\
\mathrm{OR} \cdot \mathrm{Ne}^{-1} \mathrm{Ester}\end{array}$ & $\begin{array}{c}\mathrm{ge} \\
\mathrm{OR} \cdot \mathrm{ge}^{-1} \mathrm{Ester}\end{array}$ \\
\hline 2200 & 24.8 & 11 & 620 & 174.0 & 40.1 & 16.4 & 408.4 & 96.0 & 126.3 \\
2000 & 24.8 & 12 & 600 & 174.0 & 36.4 & 15.0 & 411.8 & 94.0 & 115.1 \\
1800 & 25.2 & 13 & 570 & 176.8 & 33.3 & 13.8 & 415.6 & 95.7 & 102.9 \\
1600 & 26 & 15 & 550 & 182.4 & 30.6 & 12.0 & 392.8 & 96.9 & 111.4 \\
1400 & 26.2 & 16 & 520 & 183.8 & 26.9 & 11.3 & 417.6 & 98.9 & 89.6 \\
1200 & 25.5 & 21 & 500 & 178.9 & 22.5 & 8.6 & 381.4 & 99.2 & 103.8 \\
1100 & 25.4 & 23 & 480 & 178.2 & 20.5 & 7.8 & 381.4 & 99.2 & 106.2 \\
\hline
\end{tabular}

Comparative characteristics of the engine fuelled by diesel oil and raw rapeseed oil were performed (Fig. 5).

Comparative characteristics of the engine fuelled by diesel oil and raw rapeseed oil were performed (Fig. 6).

Comparative characteristics of the engine fuelled by diesel oil and raw rapeseed oil ester were performed (Fig. 7). 
Operating parameters...

\begin{tabular}{ll}
$+\quad$ & Diesel oil \\
& Torque \\
$-\quad-\quad$ & Hour fuel consumption Gh \\
\hdashline & Brake horsepower \\
& Unit fuel consumption ge \\
\hdashline$\quad$ & Exhaust fumes temperature Ts \\
$-\quad$ & Rapeseed oil
\end{tabular}

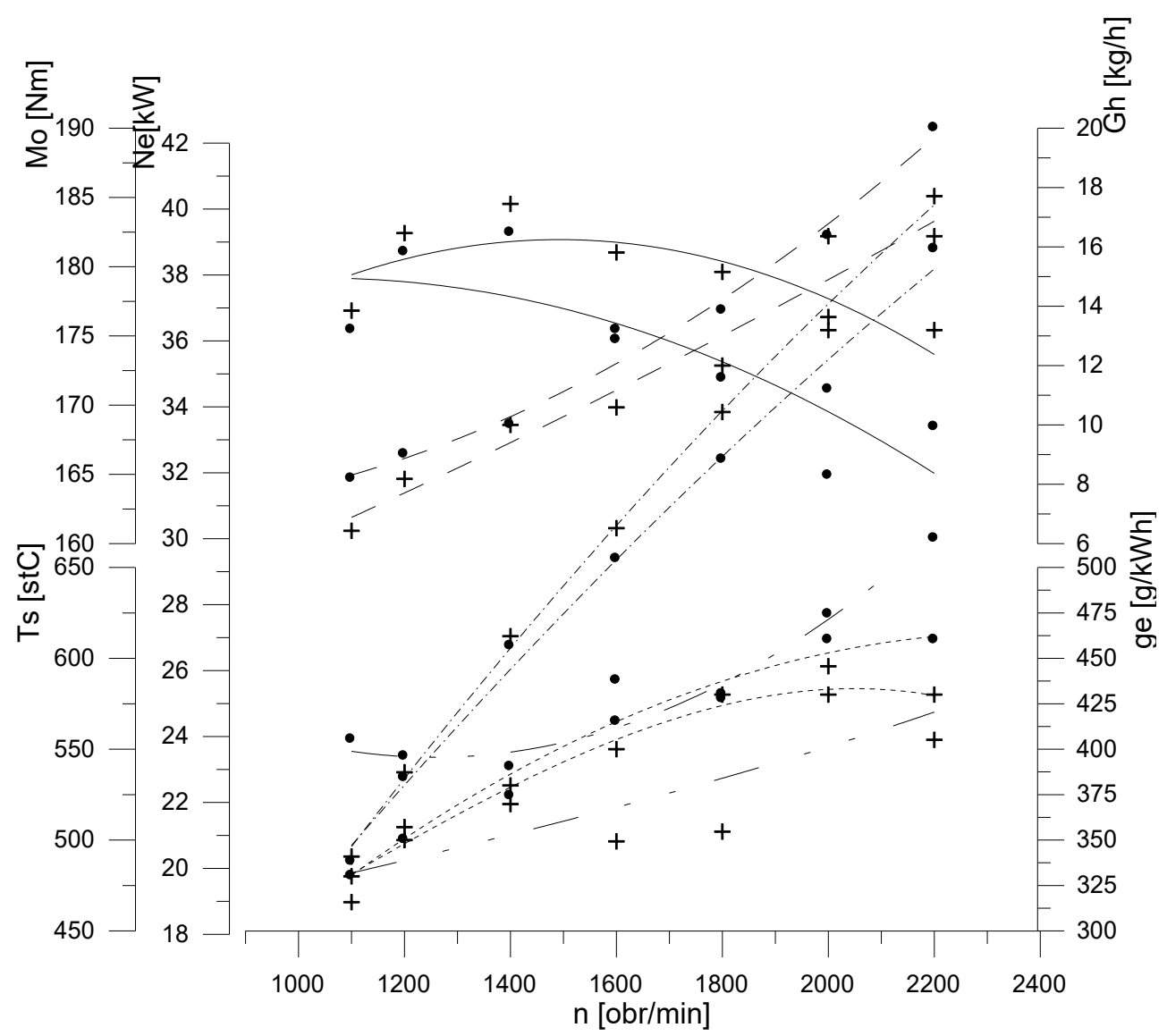

Figure 5. Comparative characteristics of an engine fuelled by diesel oil and raw rapeseed oil 


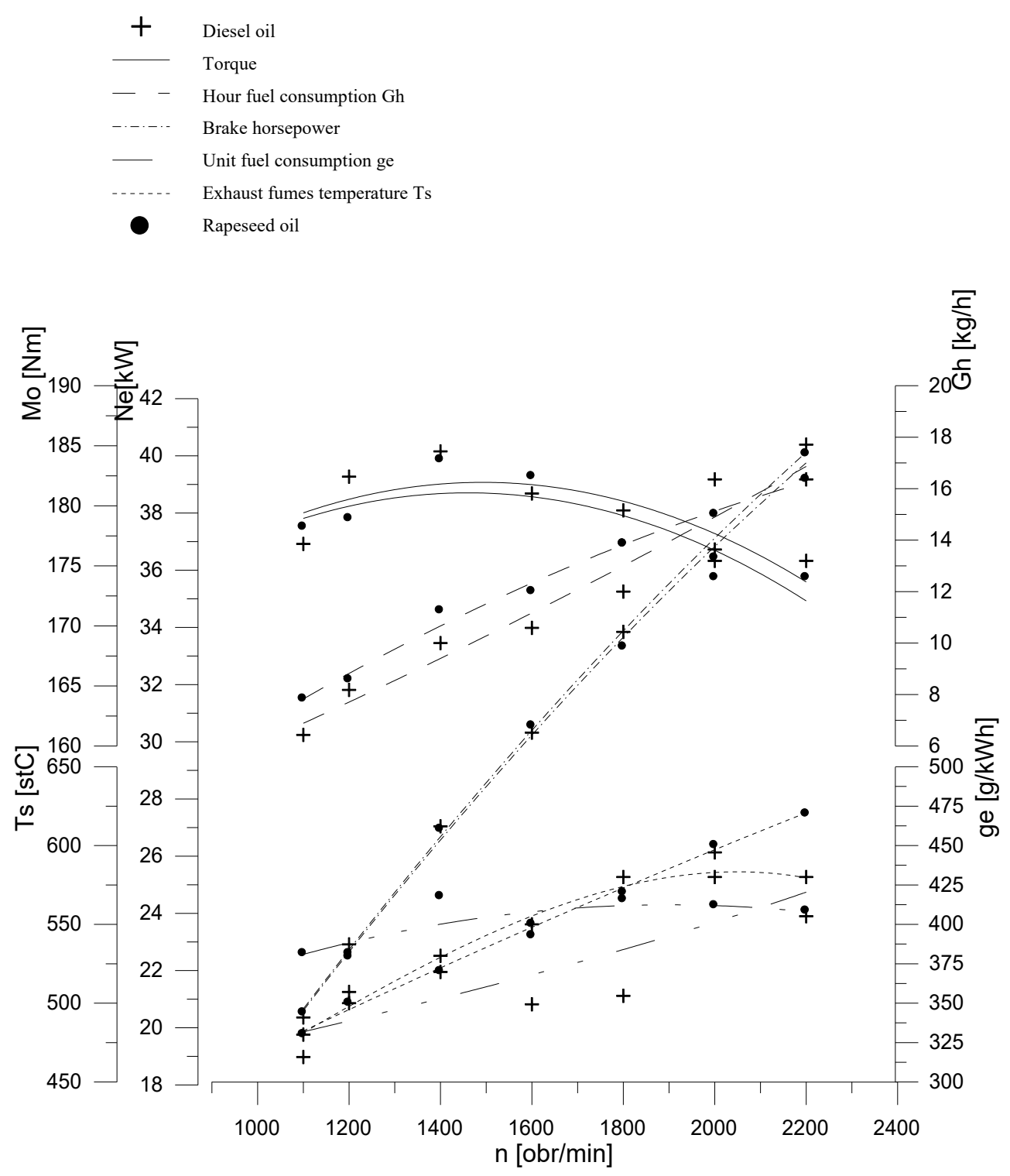

Figure 6. Comparative characteristics of an engine fuelled by diesel oil and rapeseed oil ester 
Operating parameters...

$+\quad$ Diesel oil

Torque

Hour fuel consumption Gh

Brake horsepower

Unit fuel consumption ge

Exhaust fumes temperature Ts

- Rapeseed oil

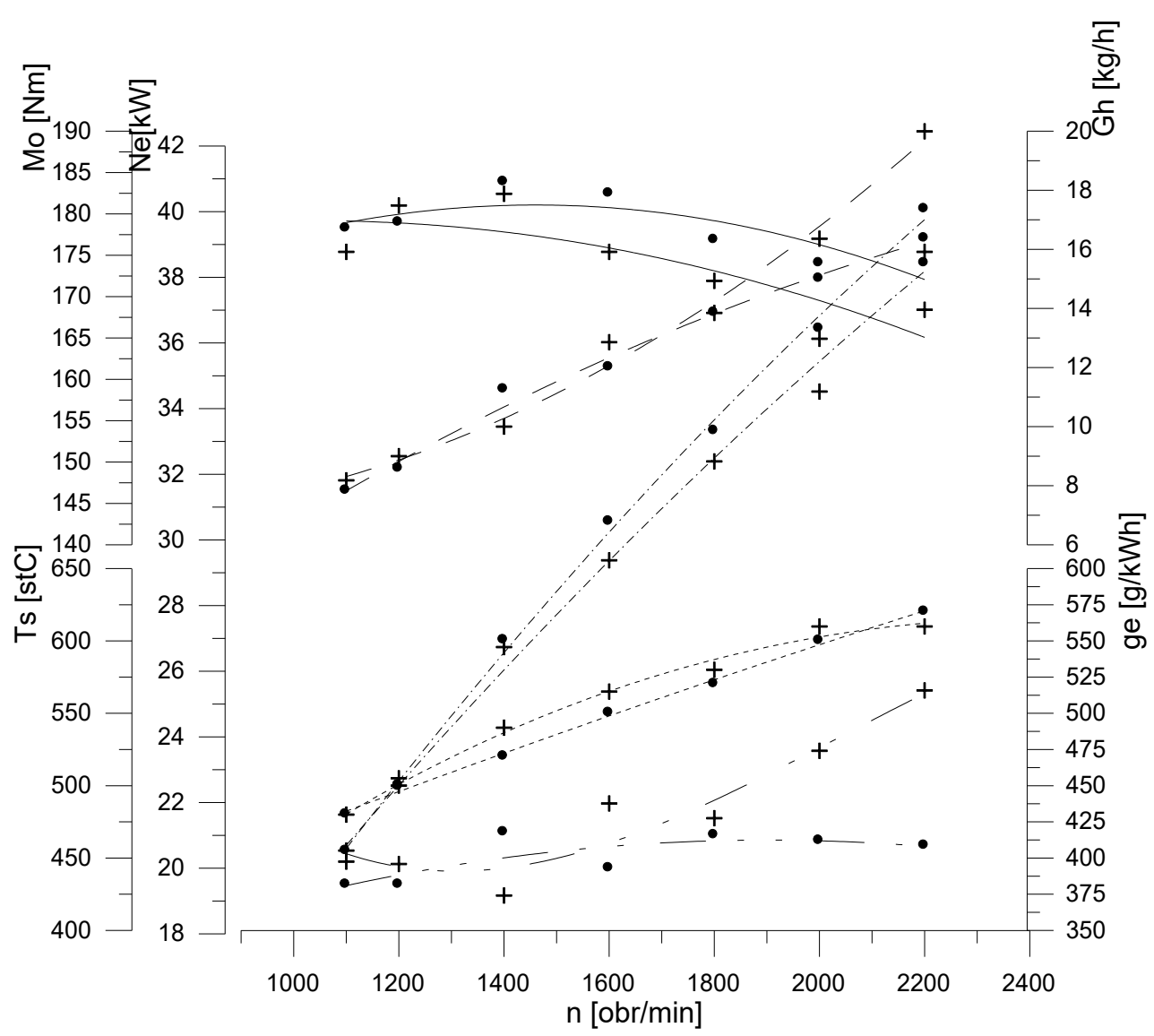

Figure 7. Operation parameters powered by raw rapeseed oil and rapeseed oil esters 


\section{Discussion}

The analysis of the data presented in fig. 5-7 and in table 1 enables indication of the following regularities:

1. The power of the engine fuelled by raw rapeseed oil and lower on average by $3 \%$ in comparison to the power of the engine fuelled by diesel oil. It is significant that the explicit reduction of power takes place within the range of the average and maximum rotational speed of the engine. The average unit consumption of fuel is higher by ca. $17 \%$ in case of powering with raw rapeseed oil.

2. In case of an engine fuelled by rapeseed oil ester, the average power is almost identical as the power of an engine fuelled by diesel oil. The average unit fuel consumption in case of an engine fuelled with rapeseed oil is higher by $9 \%$ than the unit consumption of an engine fuelled by diesel oil.

3. When comparing achievements of an engine fuelled by raw oil and rapeseed oil esters, one may notice that fuelling with raw oil causes on average $3 \%$ reduction of power and on average an $8 \%$ increase of a unit fuel consumption in comparison to fuelling with rapeseed oil esters.

4. The use of alternative fuels, especially of raw rapeseed oil, causes a reduction of the rotational speed of an engine in the entire range of rotational speeds, with a strong mark within the maximum rotational speed of the crankshaft of an engine.

5. Fuelling of an engine with biofuels causes that the temperature of exhaust gases raises. The increase of the temperature of fumes and air/fuel ratio in each condition higher than the unity may cause an increased emission of detrimental nitrogen oxides.

The issue of toxicity of exhaust fumes of an engine powered by crop-based fuels is complex and preconditioned with both fuel types and settings of an injection unit (Kowalczyk et.al., 2015).

A cursory analysis of the obtained results may also indicate that rapeseed oil esters are an optimal biofuel for powering of self-ignition engines. However, a thorough analysis requires examination of total energy inputs related to manufacturing of each investigated fuel.

Ursus C360 is a test object where a laboratory tested engine is installed. The tractor consumes 6 litres per month. Ursus 902 engine, which uses ca. 8 litres per month was also considered. The fuel costs calculated based on the theoretical fuel consumption is presented in Fig. 8 .

According to fig. 8 the costs of powering with rapeseed oil and bioester B100 seem to be more advantageous when referred to the costs of powering with a mixture B20 and diesel oil. However, the issue of various calorific value of particular fuels that determines different amounts of the consumed fuel, should be discussed, and verified.

Rapeseed oil used as a fuel has some properties that are more advantageous than diesel oil and in particular a great amount of oxygen fixed in fuel (an impact on the combustion process) and it also has very good lubricating properties. Rapeseed oil in its molecular structure includes ca. $10 \%$ of oxygen and has less carbon and hydrogen than diesel oil, therefore it has a lesser value than the calorific value (Sander et al., 2017). 


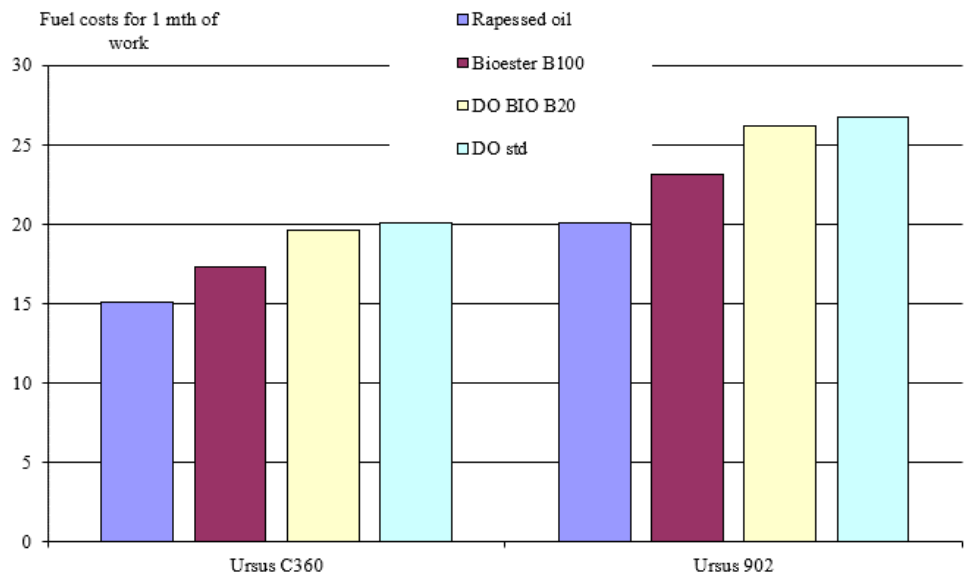

Figure 8. Comparative costs of various types of fuel referred to one moto hour of operation

When analysing the fuel costs corresponding to one moto-hour of an investigated vehicle (Fig. 9) and including the differences in the calorific value of fuel one may notice that the use of the mixture of $80 \%$ of diesel oil and $20 \%$ of rape seed esters is the most expensive. The costs of powering the vehicle with clean ester of rapeseed oil are slightly lower than the costs of powering with standard diesel oil, but it is not a significant difference. Savings at powering with raw crop-based oil (non-processed) are clearer. However, the use of such fuel requires the use of special systems that heat the fuel before supplying it to the injection unit of the engine.

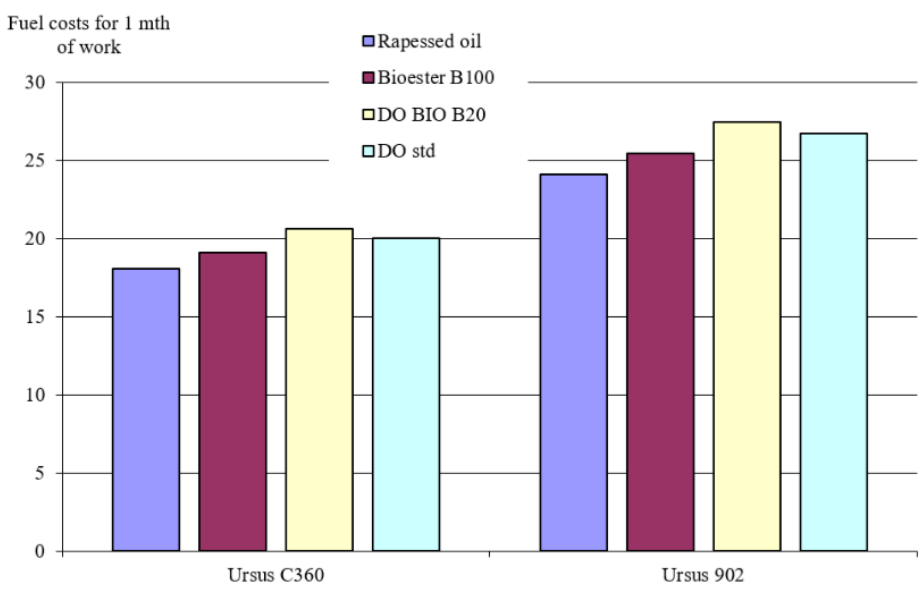

Figure 9. Comparative costs of various fuel types referred to one moto-hour of operation including various calorific value of comparable fuels 
A comparative analysis of fuel costs referred to an annual season of field works was presented in Fig. 10. It may be noticed that savings in the years' scale resulting from the use of raw rapeseed oil and esters B100 are economically justified, however, they are not too clear when compared to powering with diesel oil.

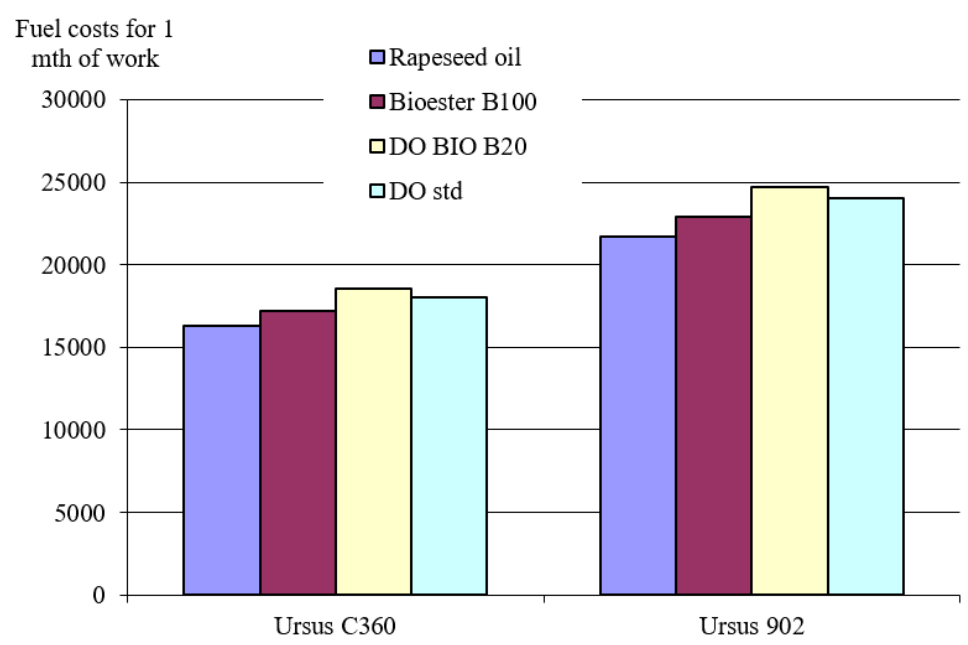

Figure 10. Comparative costs of various fuel types referred to the season of field works including various calorific value of compared fuels.

The analyses that were presented above lead to the conclusion that the use of biofuel has economic justification, which, on the other hand, is subject to the increased inputs on the technical exploitation of vehicles. It results from the increased frequency of indispensable periodical maintenance and from the increased costs of maintenance of fuel apparatus of engines powered with alternative fuels. It is worth noticing that biofuel production is related to numerous economic factors that are not included in the analyses of costs of powering a car with various fuel types.

Fuel obtained from rape seed constitutes only a part of derived goods. As it was presented above, considerable amount of pomace and glycerol phases are obtained in the esterification process. A possibility of using these additional products optimizes an economic balance of rapeseed fuel.

\section{Conclusions}

Powering of self-ignition engines with crop-based fuels is environmentally and economically justified. Nonetheless, specificity of crop-based fuels burdens environment with a high content of carbon dioxide. The influence of crop-based fuels on an injection apparatus and exploitation problems is the lowest in case of powering with plant oil esters. The use of raw plant oil may lead to the problems with the injection apparatus and requires the increase of the number of operational and diagnostic actions. 
Energy expenditures measured with $\mathrm{CO}_{2}$ emission are considerably higher at production of biofuel than in case of production of traditional fuels. However, considerable amounts of carbon dioxide are absorbed in the closed circulation in the process of photosynthesis.

Biofuel production costs are higher than the costs of production of traditional fuel. However, including residue, namely oil cake and glycerol phase after oil pressing in the economic balance and their optimal use in agriculture and chemical industry causes that costs of production of biofuel may be comparable to the production costs of diesel oil.

Biofuel consumption is higher than diesel oil consumption since the calorific value of biofuel is lower than diesel oil.

The content of toxic components of exhaust gases in case of the use of biofuels is not clear. An increased content of nitrogen oxides in exhaust gases and various levels of carbon dioxide emission and solid particles in relation to the feed system is a source of concern. However, emission of hydrocarbons is always lower when fuelling with rapeseed fuels.

The above discussion is only a preliminary study of biofuel application which may both bring many advantages, and it may be unprofitable. Everything depends on the integrity of economic, agricultural, and technical activities towards optimization of the biofuel production process and the use of any by-product.

\section{References}

Baczewski, K., Kałdoński, T. (2005). Paliwa do silników o zapłonie iskrowym. Wydawnictwo Komunikacji i Łączności, Warszawa. ISBN 978-83-206-1705-4.

Bechtold, R. (2002). Alternative Fuels Transportation Fuels for Today and Tomorrow. Wyd. SAE International.

Bocheński, C. (2003). Biodiesel paliwo rolnicze. SGGW, Warszawa. ISBN 978-83-724-4412-7.

Bocheński, C. (2006). Assessment of energy inputs and emission of gases at production of esters of rapeseed oil. Inżynieria Rolnicza, 5, PTIR Kraków, 31-37.

Dzieniszewski, G., Piekarski, W. (2006). The selected problems of feeding diesel engines with lowprocessed rape oil. Eksploatacja i Niezawodność, 3(31), PNTTE Warszawa, 58-65.

Dzieniszewski, G. (2008). Wybrane problemy stosowania biopaliw do zasilania silników z zapłonem samoczynnym. Inżynieria Rolnicza, 10(108), PTIR Kraków, 39-45.

Holt, D. (2004). Alternative Diesel Fuels. Wyd. SAE International. ISBN-13: 978-0768013313.

Jankowiak, S. (2001). Budowa i działanie wytwórni paliwa ciągnikowego z oleju rzepakowego opracowanej w PIMR. Prace Przemystowego Instytutu Maszyn Rolniczych, Nr 1, Poznań, 76-79.

Jonek-Kowalska, I. (2016). Ocena konkurencyjności biopaliw w aktualnych uwarunkowaniach technologicznych, rynkowych i prawnych. Zeszyty Naukowe Politechniki Ślaskiej, Z.97, Politechnika Śląska, 141-152.

Kowalczyk, J., Longwic, R., Lotko, W., Górski, K., Łodygowski, K., Markov, K. (2015). Wstępna analiza toksyczności spalin silnika o zapłonie samoczynnym przy zasilaniu mieszaninami oleju rzepakowego z niereaktywnym rozpuszczalnikiem. Logistyka, 3, Poznań, 2350-2359.

Lotko, W. (2007). Zasilanie silników wysokoprężnych paliwami węglowodorowymi $i$ roślinnymi. Wydawnictwo Naukowo-Techniczne, Warszawa.

Motowidlak, U. (2016). Znaczenie wykorzystania paliw alternatywnych $w$ transporcie samochodowym dla rozwoju gospodarki niskoemisyjnej Unii Europejskiej. WUŁ, Łódź. ISBN Ebooka: 978-83-8088274-4, 9788380882744

Pawlak, J. (2000). Czy biopaliwo może być opłacalne. Technika Rolnicza, 4, Poznań. ISSN 2719-4221 (online) 
Sander, P., Longwic, R., Lotko, W., Niemczuk, B. (2017). Present concept of using rapeseed oil as fuel. Autobusy, 6, 414-419.

Szlachta, Z. (2002). Zasilanie silników wysokoprężnych paliwami rzepakowymi. WKiŁ, Warszawa. $218 \mathrm{~s}$.

Tys, J., Piekarski, W., Jackowska, J., Kaczor, A., Zając, G., Starobrat, P. (2003). Technologiczne i ekonomiczne uwarunkowania produkcji biopaliw z rzepaku. Acta Agrophysica, 99, ISNN 1234-4125.

Żołądkiewicz, A. (2018). Ekonomiczno-ekologiczne aspekty produkcji biopaliw ciekłych. Roczniki Naukowe, Z.3, tom XVIII, UMK w Toruniu, 426-431.

\section{PARAMETRY PRACY I WSKAŹNIKI EKOLOGICZNE SILNIKÓW DIESLA ZASILANYCH PALIWAMI POCHODZENIA ROŚLINNEGO}

Streszczenie. Dokonano porównawczej analizy pracy silników Diesla zasilanych olejem napędowym, estrem metylowym oleju rzepakowego oraz surowym olejem rzepakowym. Przyjęto do oceny analizę charakterystyk zewnętrznych silników zasilanych różnymi rodzajami paliw. Przeanalizowano wskaźniki pracy silników, skupiając się na przebiegach mocy, momentu, jednostkowego zużycia paliwa oraz godzinowego zużycia paliwa, temperaturze spalin oraz zadymieniu. Dokonano efektywności pracy silników przy zasilaniu różnymi rodzajami paliw i wskazano na optymalne proporcje mieszanin paliwowych. Przeanalizowano ekologiczne aspekty zasilania silników paliwami konwencjonalnymi oraz paliwami pochodzenia roślinnego. Przyjęto jako kryterium oceny parametrów ekologicznych sumaryczną emisję $\mathrm{CO}_{2} \mathrm{w}$ całościowym procesie wytwarzania i spalania paliw. Dokonano uproszczonej analizy ekonomicznej w aspekcie celowości stosowania paliw pochodzenia roślinnego do napędu silników tłokowych. Wypracowano wnioski i rekomendacje wyznaczające kierunki rozwoju w zakresie analizowanego zagadnienia.

Słowa kluczowe: silniki spalinowe, paliwa pochodzenia roślinnego, charakterystyki zewnętrzne silników spalinowych 